\title{
Designing learning tools by using problem based instruction model on science integrated to character education
}

\author{
Estuhono $^{1}$, Joni Afriko ${ }^{2}$ \\ 12Universitas Dharmas, Dharmasraya - Indonesia, (estuhono023@gmail.com)
}

\begin{abstract}
The integrating of character values into science learning tools should be able to build character for the students. The purpose of this research is to design science learning tools by using problem based instruction model on science for elementary school that is integrated by education character values. The research was Research and Development. The Learning tools were developed by using 4-D model (Define, Design, Develop and Disseminate). In the define phase, there is curriculum analysis, students analysis and analysis of the material. Design phase is to design science learning tools by using problem based instruction model that is integrated by education character values, develop phase is to develop innovative science learning tools by using problem based instruction model and disseminate phase is to spread science learning tools by using problem based instruction model that is integrated by education character values. The data are collected by using a validation sheet of learning tools, practicality questionnaires and instrument of effectiveness. However, this research is still at the design stage. Based on analysis curriculum got, curriculum at elementary school is still applying KTSP. Then based on analysis of students, it reveals that the students of elementary school are at the stage of concrete operations. Then, the material, it shows facts, concepts, principles and procedures that integrate the character values of education. The results of the Design stage, reveals that syllabus, lesson plan, worksheet, assessment designed following the steps of PBI model integrated by character education.
\end{abstract}

Keywords: learning tools, problem based instruction, science, and character education

\section{Introduction}

Organizing character education is one thing that is done in every level of education, especially in elementary education level. This is very reasonable because basic education is the main foundation for young people's growth. Kemendiknas (2010: 4) explains that "Character education is interpreted as an education that develops the values of the characters in the learners themselves so that they have values and character as a character of himself, applying these values in his life as members of society, and citizens who religious, nationalist, productive and creative ". This shows that the students' character values can be nurtured through a continuous and integrated education process.

The values of character education obtained by the students from the result of integrating the value into the learning process that is implemented for all subjects. It means that, in a learning process, in 
addition to targeted students to master a particular learning material, students also recognize, realize and internalize the values of character education through the integration of the character's values in each subject.

Natural Science as one of the subjects taught in elementary school of course can also be used as a means of implementing the values of character education. Science is a science subject that explains various physical phenomena phenomena that occur in nature, both theoretically and mathematically. This clearly indicates that there are spaces that can be used as a means in developing the values of character education to students in science learning

Based on the results of discussions and interviews conducted by researcher at the time of carrying out Community Service Activities on the integration of character education together with elementary school teachers in Dharmasraya District on January 23th, 2017 obtained information that, the primary school learning has not integrated the values of education character both in terms of the learning process and the development of learning tools. The learning process that has occurred so far has not linked the learning materials with the character education values. This is suspected because the development of learning tools that teachers do so far also still not integrate the values of character education in it.

Achievement of science learning objectives is determined by the learning tools used by teachers. In general, the learning tools used in science teaching in elementary schools are quite diverse. However, there are components of learning devices that are used still need to be fixed. The learning tools that must be improved include syllabus, lesson plan, teaching materials, Student Worksheet and assessment. The syllabus used is still not specific and not in accordance with the characteristics of students, it is seen from the indicators of achievement of competence and learning activities contained in the syllabus. In addition to syllabus, lesson plan used by teachers also still needs to be improved. The compiled lesson plan is actually based on Permen 41 of 2007, but there are some components of lesson plan that are still not complete. The fundamental thing that still needs to be improved is that in the lesson steps have not yet integrated the values of character education to be developed. Furthermore, teaching materials used natural science can not accommodate the values of character education in accordance with the characteristics of students. Other learning tools that should also be improved are the Student Worksheet. The worksheet used is also not in accordance with the characteristics of students and school conditions. This causes student learning activities less than the maximum. Meanwhile, in terms of assessments used by teachers, it appears that the indicator of student competence is not in accordance with the assessment used by teachers, so the assessment is not maximized. Based on the analysis of all learning devices used by teachers so far has not integrated the values of character education in it.

One of the strategic efforts that can be done to overcome the above problems is through the development of a natural science learning tool that integrates character education values that are appropriate to the characteristics of the students. Natural science learning tools that will be developed consist of syllabus, RPP, teaching materials, worksheets, and assessment. Meanwhile, teaching materials that will be developed in the form of learning modules that will be expected to facilitate students learn anytime and anywhere. The development of integrated learning tools of natural science character education follows the steps of Problem Based Instruction model. This is effective because the Problem Based Instruction model is a constructivist-based learning model that accommodates students' involvement in authentic learning and problem solving. Through the application of the PBI model into the learning tools that are enabled to enable students to learn actively, fun so it is expected to foster positive characters in students.

Some efforts to develop PBI-based learning tools have been done before, such as research conducted by Diani (2015) which concluded that the development of high-school physics learning devices based on character education with PBI model can improve student character behavior such as 
honest character, hard work, discipline, curiosity know, religious, critical thinking, and cooperation. Diani (2015) develops learning tools not for science subjects in elementary school but for physics subjects at high school level. Furthermore, research conducted by Asyhari, et al (2014) which concluded that the development of inquiry-based physics-based learning tools integrated character education is able to foster the values of student character. However, learning tools are also developed for high school physics while the model used is a guided inquiry model. Based on this description, it is necessary to do research on the development of natural science learning tools based on the Model of Integrated Character Education PBI with for Elementary School Students.

\section{Method}

The type of research used in this research is research development (Research and Development). In design science learning tools by using problem based instruction model that is integrated by education character values, this study uses 4-D model consisting of 4 stages: define, design, develop, disseminate. However, this study only reached the design stage. In the define phase, there is curriculum analysis, students analysis and analysis of the material. Design phase is to design science learning tools by using problem based instruction model that is integrated by education character values, develop phase is to develop innovative science learning tools by using problem based instruction model and disseminate phase is to spread science learning tools by using problem based instruction model that is integrated by education character values. The data are collected by using a validation sheet of learning tools, practicality questionnaires and instrument of effectiveness. However, this research is still at the design stage. Based on analysis curriculum got, curriculum at elementary school is still applying KTSP. Then based on analysis of students, it reveals that the students of elementary school are at the stage of concrete operations. Then, the material, it shows facts, concepts, principles and procedures that integrate the character values of education. The results of the Design stage, reveals that syllabus, lesson plan, worksheet, assessment designed following the steps of PBI model integrated by character education.

\section{Results and Discussion}

\section{Definition stage}

The defining stage is the first stage in the development of learning tools with the aims to define the requirements of learning by analyzing the learning objectives of the materials developed learning tools. In this defining phase, curriculum analysis is done, analysis of student characteristics and analysis of science materials.

\section{Curriculum Analysis}

According to Permendiknas No. 22 of 2006 shows, the development of curriculum is accordance with the principles of development such as student-centered and environmental interests, diverse and integrated, relevant to the needs of life. At the stage of curriculum analysis, the competency standards and basic competence analysis are devoted to natural science. Furthermore, Permendiknas No 41 of 2007 shows on the standard process established by the government for the first educational unit includes the planning of learning process, the implementation of the learning process, assessment of learning outcomes, and supervision of the learning process. Planning the learning process includes the syllabus and lesson plan. The facts in the field indicate that most of teachers are poorly prepared in planning as for example in making lesson plan for each meeting. The lesson plan used usually still uses pre-existing and has not developed innovative lesson plan and integrate character values especially natural science.

Lesson plan includes activities in the learning process. Implementation of learning requires the inculcation of positive character of students in supporting the achievement of one of the principles of 
learning objectives, especially affective aspects. Based on field observation, each teaching implementation tends to be centered on the teacher (teacher centered) so it tends to give less opportunity to the students to develop character values. Analysis of assessment tools shows that teacher still prioritize cognitive aspects. Affective aspects/characters and psychomotor cannot be found in the assessment process in the classroom

\section{Material Analysis}

Material analysis is important before the development of the tool because it is used as a basis in knowing the relevant materials with the curriculum demands so that it can be used to synergize the learning model suitable to achieve the learning objectives. Material analysis also provides an overview of the models and approaches that are effectively used in achieving the expected goals. Material analysis is the identification of the main materials that will be taught and arranged systematically in order to find relevance concepts into everyday life reality. This analysis is aimed to identify, detail, and systematically prepare the key principles of natural science materials by integrating the character values.

Based on the analysis of the material conducted, it can be seen the general description of the appropriate learning tools for natural science and simple works as well as the syllabus, lesson plan, worksheet and assessment used in the learning. Learning tool of natural science is a set of teaching materials that can be used by students in studying natural science materials in growing character values in students and assisting teachers in implementing learning natural science. Worksheet is used as a guide to find the concepts studied, while the assessment is used to determine the students' competence.

\section{Analysis of Students' Characteristics}

Analysis of the students' characteristics is a study of the characteristics in accordance with the design of development of science learning tools on natural science integrated to character values. Analysis of student characteristics is a study of the characteristics of students related. This analysis is done to get a description of the characteristics of students, among others: (1) the level of ability or intellectual development, (2) the background of experience, (3) cognitive development, (4) learning motivation, (5) as well as skills possessed participants educated, this stage is done to obtain information about the actual conditions that occur in the field. The main problem faced by students is the absence of integration of energy-saving character in the learning process that is on science subjects of natural science, so that impact on the development of character values in student self. Based on the analysis found it can be a foundation to develop learning tools in accordance with the needs of students on the material of natural science is the development of science learning tools based PBI model on the natural science.

\section{Design Stage}

The design stage is the second stage in device development. Based on the results of the design obtained model of learning Problem Based Instruction. The PBI model is a model of learning that centers on problem-solving skills through the development of broad-minded creativity in order to apply learning concepts to solve everyday phenomena. This is highly relevant to the concept of the PBI model which is a constructivist-based learning model that accommodates students' involvement in authentic learning and problem solving. Through the application of the PBI model into the learning tools that are enabled to enable students to learn actively, fun so it is expected to grow a positive character, especially students' characters. The result of design of learning device that is produced include syllabus, Lesson Plan, Worksheet, and assessment based on Problem Based Instruction based learning model integrated with character value.

\section{Conclusions}

Based on the research that has been done can be concluded several important points as follows: 
1. Based on the curriculum analysis that implemented at elementary school is KTSP.

2. Based on the analysis of student characteristics, the integration model has an opportunity to develop students' character values in problem solving as well as the opportunity to grow energysaving character for students.

3. Based on the analysis of the material, it can be found general description of the appropriate learning model used in studying natural science and know the form of effective learning tools to be developed by integrating the character values in education.

4. The results of the design stage obtained a model Instructional strategy used is a model of Problem Based Instruction (PBI) learning that is integrated with the values of the character. Therefore, this study produces learning tools in the form of syllabus, Lesson Plan, Worksheet, and assessmentbased Problem Based Instruction (PBI) model.

\section{Acknowledgments}

The researcher would like to thank all parties who have supported the implementation of this research, especially to Kemenristekdikti and the Faculty of Teacher Training and Education Universitas Dharmas Indonesia.

\section{References}

Asyhari, dkk. (2014). "Pengembangan Perangkat Pembelajaran Fisika SMA Berbasis Inkuiri Terbimbing Terintegrasi Pendidikan Karakter". Jurnal Inkuiri,3(1):62-75)

Batdi, V. (2014). "The Effects of a Problem Based Learning Approach on Student's Attitude Levels: A Meta- Analysis". Academic Journal, 9(9):272-276

Depdiknas.(2010). Pedoman Pengembangan Perangkat Pembelajaran KTSP. Jakarta: Depdiknas.

Diani. (2015). "Pengembangan perangkat pembelajaran fisika Berbasis pendidikan karakter dengan model Problem based instruction". Jurnal Ilmiah Pendidikan Fisika 'Al-BiRuNi', 4 (2): 243-255

Kemendiknas. (2010). Pengembangan Pendidikan Budaya dan Karakter Bangsa. Jakarta: Depdiknas

Khusniati. (2012). "Pendidikan Karakter Melalui Pembelajaran IPA". Jurnal Pendidikan IPA Indonesia, 1 (2) : 204-210

Kurniawan. (2013). “Integrasi Pendidikan Karakter Ke Dalam Pembelajaran Kewarganegaraan Di Sekolah Dasar". Jurnal pemikiran dan pengembangan SD, 1(1) : 37- 45

Permendiknas Nomor 41 Tahun 2007 tentang Standar Proses.2007 Jakarta: BSNP

Rawa, N, dkk. 2016. "Pengembangan Perangkat Pembelajaran Berbasis Model Learning Cycle-7E Pada Materi Trigonometri Untuk Meningkatkan Kemampuan Koneksi Matematis Siswa". Jurnal Pendidikan, 1(6): 1042-1055

Riduwan. (2009). Belajar Mudah Penelitian untuk Guru, Karyawan dan Peneliti Pemula. Bandung: Alfabeta.

Sanjaya, Wina. (2010). Perencanaan dan Desain Sistem Pembelajaran. Jakarta: Kencana.

Sudjana. (2008). Dasar-Dasar Proses Belajar Mengajar. Bandung : Sinar Baru Algesindo.

Trianto.(2007). Model Pembelajran Inovatif Berbasis Konstruktifistik. Jakarta:Prestas Pustaka

Trianto. (2010). Pengantar Penelitian Pendidikan bagi Pengembagan Profesi Pendidikan \& Tenaga kependidikan. Surabaya: Prenada Media group.

Zulnuraini. (2012). "Pendidikan Karakter: Konsep, Implementasi Dan Pengembangannya di Sekolah Dasar di Kota Palu". Jurnal DIKDAS, 1 (1):1-11 